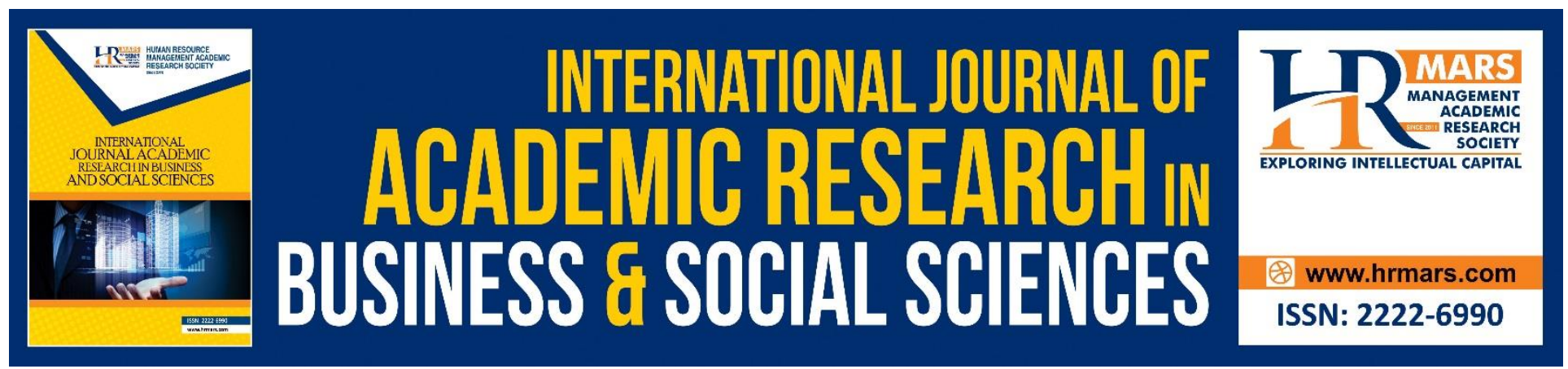

\title{
Assessing the Relationship between Promotional Tools and Tourists' Intention to Visit the National Prison Museum in Melaka
}

Arni Abdul Gani, Aida Syafinaz Khairudin, Munirah Kadir, Syamil Farmy

To Link this Article: http://dx.doi.org/10.6007/IJARBSS/v11-i13/8554

DOI:10.6007/IJARBSS/v11-i13/8554

Received: 23 November 2020, Revised: 18 December 2020, Accepted: 05 January 2021

Published Online: 26 January 2021

In-Text Citation: (Gani et al., 2021)

To Cite this Article: Gani, A. A., Khairudin, A. S., Kadir, M., \& Farmy, S. (2021). Assessing the Relationship between Promotional Tools and Tourists' Intention to Visit the National Prison Museum in Melaka. International Journal of Academic Research in Business and Social Sciences, 11(13), 362-374.

\section{Copyright: (c) 2021 The Author(s)}

Published by Human Resource Management Academic Research Society (www.hrmars.com)

This article is published under the Creative Commons Attribution (CC BY 4.0) license. Anyone may reproduce, distribute, translate and create derivative works of this article (for both commercial and non-commercial purposes), subject to full attribution to the original publication and authors. The full terms of this license may be seen

at: http://creativecommons.org/licences/by/4.0/legalcode

Special Issue: Beyond 2021 and COVID-19 - New Perspective in the Hospitality \& Tourism Industry, 2021, Pg. 362 - 374

Full Terms \& Conditions of access and use can be found at http://hrmars.com/index.php/pages/detail/publication-ethics 


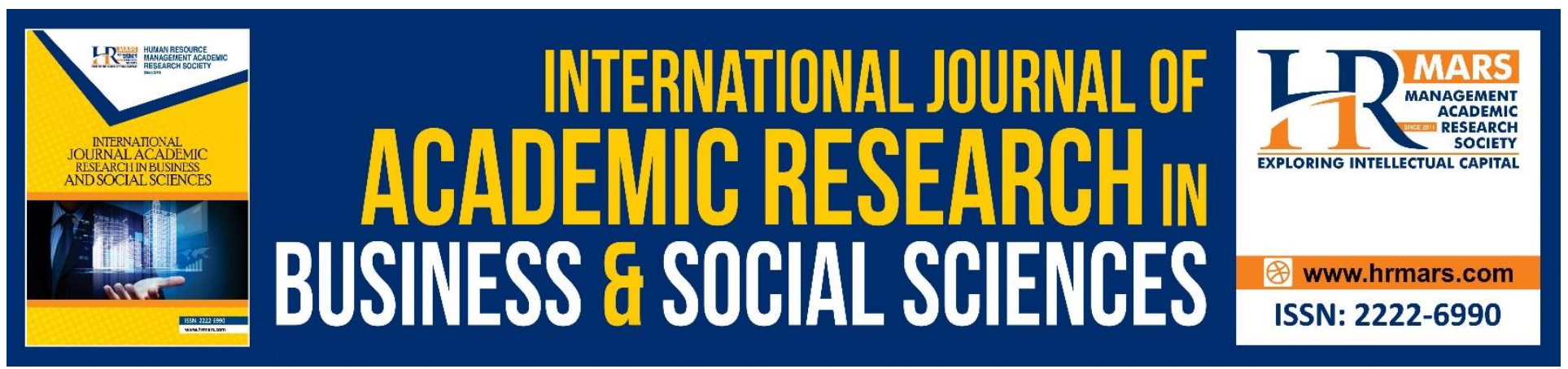

\title{
Assessing the Relationship between Promotional Tools and Tourists' Intention to Visit the National Prison Museum in Melaka
}

\author{
Arni Abdul Gani, Aida Syafinaz Khairudin, Munirah Kadir, Syamil \\ Farmy \\ Faculty of Hotel and Tourism Management, Universiti Teknologi MARA, Selangor, Malaysia
}

\begin{abstract}
Assessing the intention of tourists to visit an attraction is crucial for marketers, and especially significant in turmoil conditions such as during and post pandemic. For a special niche attraction that promotes dark tourism like prison, promotional tools are important to set a desirable image for tourists. This paper investigates the relationship between promotional tools and tourists' intention to visit the Malaysia Prison Museum, Melaka. The questionnaires were posted online on various platforms, and tourists who had not experienced visiting the attraction were selected as respondents. The results indicated that promotional tools were perceived important and were found positively related to their intention to visit. However, some issues concerning the applicability of different promotional tools surfaced. In today's digital world, having a great webpage and continuous updates on social media is inevitably one of the key successes in marketing. Furthermore, the study also concluded that the lack of support from the government and management in promoting the museum is probably the main reason why this attraction has yet to receive tourists' attention. This study provides good insights in tourists' perception of promotional tools used in niche market; which is dark tourism, and how it can motivate them to visit. The outcome of the study can be used as a guideline for any prison museum management that promotes dark tourism to develop more efficient and updated promotional tools and strategies.
\end{abstract}

Keywords: Promotional Tools, Dark Tourism, Museum, Intention to Visit, Perception of Tourist.

\section{Introduction}

Tourism comprises several types of segmented attractions. A mass tourism attraction includes nature, islands, and mountains, but a more focus-oriented tourism attraction includes gastronomic tourism, culture-based tourism, rural and community-based tourism, wildlife, green, and even dark tourism. As stated by Hartmann (2014), Logan and Reeves (2009), as well as Stone and Sharpley (2008), the start of dark tourism market is a result of a switch phenomenon in tourists' interest, and this is not new in tourism industry. Dark tourism is defined as "the act of travel to sites associated with death, suffering, 
and the seemingly macabre" (Stone, 2006, p. 146). Furthermore, it is seen as an activity of visiting places that represent misery, catastrophe, crime, disaster, or death. The focus on the latter also means that it is associated with the extensive 'thanatopic' tradition (Foley and Lennon, 1996; Sharpley, 2009; Stone, 2006). As tourism becomes more accessible, the constant desire of tourists for something new has had some impact on the popularity of these 'dark' places and it is reported that hit or searches for dark tourism on the internet has risen to 4 million in 2017 (Light, 2017).

Malaysia is famous for its gastronomy, cultures, and Muslim-friendly destinations. Melaka, for example, is well-known for culture, heritage, food, and history. Mahorm (2018), in an article published by The Star mentioned that Melaka is a second topmost visit destination by tourists in Malaysia with an achievement of having 17.02 million tourist arrivals in 2018 . From the figure, 11.33 million or $66.6 \%$ were domestic tourists while the remaining 5.68 million or $33.4 \%$ were foreign visitors. One of the iconic attractions in Melaka are the museums. There are more than ten existing museums in Bandar Hilir, Melaka which were established in the ancient times, such as Maritime Museum (Flor de la Mar), Folk Museum, Museum of Stamps Melaka, and Melaka Sultanate Museum. These museums are famous for their history that relates to the Melaka Sultanate era. The management which falls under the responsibility of Perbandaran Muzium Melaka (PERZIM) preserve their own heritage values. It is interesting to note that Melaka also has a dark tourism attraction, i.e., the Malaysia Prison Museum. It is the second oldest prison in Malaysia after Jerejak Island, Bidong Island, and Batu Lintang, Kuching (Braithwaite \& Lee, 2006) and has been established as a tourism attraction since 2014.

For museums, the support from government bodies, public agencies, travel agencies, and tour operators are important to ensure this particular type of attraction exist in the minds of the tourists when planning their tours. However, it is sad to admit that lacking in terms of support is the reason why this type of attraction is facing challenges to grow (Bhuiyan, Siwar \& Ismail, 2013). Zahari, Hanafiah, Mahbob, and Zain (2016) also agreed with the statement as tourism stakeholders in Malaysia show less interest in promoting this particular product. Cavlek (2002) argued that, in order to be sustainable, any existing or new tourism product should be aggressively promoted through the communal efforts of all those involved in the tourism industry. For this reason, it is clear that there is a need for a strong collaboration and commitment on the part of the tourism stakeholders to develop and promote dark tourism sites. Three aspects in the management of places of death and suffering (dark tourism) for tourists are management of problems, interpretation, and marketing or promotion (Light, 2017).

Mat Som (2014) stated that only about 100,000 domestic and international tourists had visited Malaysia Prison Museum located in Bandar Hilir Melaka since its operation in 2010. This indicates that the area is receiving less attention although it has been operated for a decade.

Compared to other popular museums nearby such as Maritime Museum Complex, they have received about 171,657 visitors from January until August in 2019 alone and more than ten million in the past five years (PERZIM, 2019). Hence, Malaysia Prison Museum is left very far behind. Understanding the dimensions of tourists' consumption value might have an important impact on improving the value perceived by tourists to settle for dark tourism. Therefore, promotional tool is crucial in marketing 
the attraction to raise awareness and draw tourists' intention to visit. It has been proven that this tourist attraction spot was not challenged in its promotion strategy. Thus, this study is aimed to (i) to identify the perception of tourists on promotional tools used by Malaysia Prison Museum and (ii) to assess the relationship between promotional tools and tourists' intention to visit Malaysia Prison Museum. Up to this date, multiple studies on dark tourism have been conducted in Malaysia, looking at motivational factors (Mahbob et al., 2013; Khamis \& Syariff, 2016), importance of dark tourism in war and memorial places (Braithwaite \& Lee, 2006), acceptance towards locals (Masanti, 2016), tour operators' perceived value (Zahari et al., 2016), and potentials of dark tourism (Tan \& Lim, 2018). However, limited studies measured the effectiveness of promotional tools for this unique type of tourism. Hence, an empirical investigation needs to be undertaken to fill the gap of such studies, particularly looking at prison museums in Malaysia.

\section{Literature Review}

\section{Prison as Dark Tourism Attraction}

Prison tourism can be considered as part of an unusual practise known as 'shadow' tourism (Clarke, Dutton \& Johsnton, 2014). It is a growing attraction but not the latest trend in tourist attraction. Prison tourism sites are also called prison museums due to their relatedness in conserving and exhibiting historical, social, and/or cultural objects or interests in architecture. Therefore, they possess many features of traditional museums. They are places where human misery, black site of death, and suffering occur (Sharpley, 2009). Welch and Macuare (2011) claimed that representations of unoccupied prisons can re-enhance public discourse on contemporary prisons. Their representations may become "monumental museums" (Walby and Piche, 2011: 452) reflecting and even replacing the frameworks they have in the general public. Their views are becoming facts for the public.

Prison visitors observe the neutral collection or objects inside a museum. They somehow engage in a project in which the present draws on previous events to construct its modernity (Welch \& Macuare, 2011). For these reasons, the image of jail history in prison museums plays a vital role in influencing the viewers' opinions regarding contemporary punishment. The prison museums also vary as far as education and entertainment are concerned (Ross, 2012). According to Yilmaz (2009), one of the ways to attract the visitors is by participating in the prisoners' production such as handicrafts like carpentry, joinery, and carving that exist in the prisons. As an instance, a case of Sinop Fortress Prison which became popular because of the visitors could not escape into the historical phase, thus, handmade prison ornaments contributed significantly to the promotion of Sinop.

Malaysia Prison Museum which operates in Melaka city is one of the tourist attractions that allows exploration of the interior of a former jail which has been turned into a museum. This museum focuses its eyes on Malaysian jails; both from the past and present prison systems that had been used since 18th century. It was developed under the British rule and second oldest in Malaysia after Jerejak Island. Ambience inside of the prison museum can be felt practically due to its 'prison' vibes when tourists visit exhibits, such as the isolation cells, questioning rooms, and hanging gallows. The immersive videos on corpuscle punishment and the interior of jail cells make it more disturbing, especially for small children. Tourists who explore a prison are regarded as emotionally strong. It is indeed part of the political tactics for advocates who seek to criticise prisons and punishment attitudes 
and to keep prison discussions alive. The museum is also used to display photographs of original sketches and scrawler walls by the inmates, as well as pictures of the inmates' buttocks during the abuse of the whipping cane. The historical context and imagery which have been built over time appear more real over prisons. These earlier texts' haunted' the current architectural space (Fiddler 2011).

\section{Destination Marketing for Dark Tourism}

Marketing is the performance of business activities that direct the flow of goods and services from producers to consumers. Under marketing mix, there is the existence of promotion, i.e., a dimension known as promotional tools, which is subject to internal and external circumstances. As stated by Peattie and Peattie (1994), usually it is the time, place, or customer community that promotes customers' direct responses or marketing intermediaries through the additional advantages offered. According to Minic (2012) promotions of dark tourism should exist and it is part of the key areas of dark tourism industry. The benefits of good promotions will be great if the attraction is properly valued and the supply is properly placed on the market.

For a unique attraction like dark tourism, marketing needs more considerable efforts. The popularity of dark tourism is dependent on the number of tourists opting for vising dark sites. Motivating factors for tourists can be clubbed into biological and socio-cultural forces that stimulate the behaviour of people. The desire to explore the unknown and unusual or paranormal can be considered as the pushing factors for dark tourism (Saha, 2020). Marketing and promotional efforts must be tailored and meet the specificity of the market.

Sharpley (2009) emphasized that dark tourism popularity has been greatly increased by the advertising that mass media can provide. Stone (2009) agreed that the media of advertising have a strong connection with dark tourism and a widespread of media reports have succeeded in integrating the prison into popular culture (Wright \& Cropanzano, 2000). Moreover, as mentioned by Govers and Go (2003), the consumers of tourism are 'actively engaged in developing and adding value to the picture of the tourist destination'. In advertising, there are things which need to be considered while planning, such as objective setting, budget calculation, message decisions, and campaign evaluation (Pike, 2004).

On the other hand, Farooq (2018) indicated that public relations differ a lot from advertising and are more important than these ads. The interaction between the media and other individuals involves news stories, incidents, and features which are considered more genuine. It is known as consumer "news" rather than a correspondence that focuses on sales. Public relations are known as the result of an organization where the methods are specific to press releases, newsletters, press conferences, and news reports. For coverage of notable business activities, small companies often must establish relationships with the local newspapers and TV stations (Kokemuller, 2019). Kešetović (2011) stated that public relations' approach should be used for future crisis management and preparedness measures for dark tourism, especially in terrorism attack sites. It is important in creating the desire for potential tourists to visit. Seitel (2001) mentioned that the roles of public relations help to create and sustain reciprocal ties between the authorities and tourists. Giving visitors knowledge 
about the area becomes a basic cornerstone and essential for developing a relationship, especially in marketing dark tourism.

Another form of marketing that is fast becoming significant is internet marketing. It is known as digital marketing which acts as a key strategy in gaining popularity for a destination to grow (Makosa, 2019). According to Kaur (2017), digital marketing today has become an indispensable part of every business irrespective of its nature and size, especially in tourism industry. It is then, being revolutionize as interactive marketing where customers can connect and communicate with the buyer. Under interactive and internet marketing, there are social media, websites, emails, electronic word of mouth (e-WOM), blogs, and even video blogs (VLOG). In the last two decades, the use of internet increased and therefore, the Destination Management Organisation (DMO) such as dark tourism industry has to consider an online marketing way as well (Jahnke, 2013). Social media play an increasingly important role in the travel industry as they reshape the way travellers search for information, create a plan, and decide to travel (Leung \& Bai, 2013; Xiang \& Gretzel, 2010). Based on these studies, lacking information or knowledge regarding the site, especially dark tourism, makes a person less interested and intention to visit. Garcia (2012) mentioned that this approach is even important for dark tourism industry and employing such approach has shown some evidence of increased visitation.

The objective of most marketing strategies attempts to influence behavioural intentions and increase probability for travellers to visit (Hennessey, Yun, \& MacDonald, 2016). The prediction of visitors' future behaviour is therefore a vital part of planning and forecasting the number of visitors for marketers. Tracking visits with actual visits is an important measure in the effectiveness of a marketing strategy for many tourist destinations. This is because tourists' intentions are formed through a rational choice and decision as Vogt, Winter, and Fried (2005) indicated, intentions are assumed to accurately predict actual behaviour. For the case of Melaka Prison Museum, the responsibilities of marketing rely on PERZIM as the management authority and efforts have been made to market the place as a dark tourism attraction in Melaka. Advertising, public relations, and online marketing have been conducted to promote this place; however, the number of visitors has not been likely to show the successfulness of the efforts made. As mentioned earlier, the Melaka Prison Museum is not receiving a comparable amount of visitors as other museums under PERZIM.

\section{Methodology}

To determine the relationship between promotional tools and tourists' intention to visit, a descriptive research design was used along with a quantitative approach through the present crosssectional study. The instrument developed was adapted from the previous studies by Arshad and Aslam (2015); Alananzeh et al (2015); Weng \& Huang (2018); Kennedy (2016) and Hidayat and La Are (2018). A pilot study was conducted prior to the data collection phase and the reliability values obtained for all the variables tested were above 0.70 . 
The questionnaires were distributed using social media platforms, and a non-probability sampling technique was employed. Based on the latest number of tourists visiting Melaka, the targeted respondents were 382. The respondents were tourists who visited Melaka and must satisfy the screening question and had no experience visiting Melaka Prison Museum. Respondents were asked for permission prior to their agreement to participate in the survey. Attached together with the questionnaires were examples of marketing materials of Melaka Prison Museum. These were the actual materials used by PERZIM which comprise of media advertising, paper cutting of public relations programs ran by the prison, and four webpages and social media accounts of the prison. A total of $\mathbf{3 7 9}$ were successfully obtained and after undergoing the data cleaning process, a valid of 316 responses were analysed. Correlation analysis was used to determine the level of correlation between the perceptions of tourists of the promotional tools used (independent variables) towards intention to visit (dependent variable) the Malaysia Prison Museum.

For this study, the hypotheses proposed were as stated below:

$H_{1}$ : There is a relationship between promotional tools and tourists' intention to visit.

$H_{1.1}$ : There is a relationship between advertising and tourists' intention to visit.

$H_{1.2}$ : There is a relationship between public relations and tourists' intention to visit.

$H_{1.3}$ : There is a relationship between interactive and internet marketing and tourists' intention to visit.

\section{Result and Analysis \\ Demographic Analysis}

The total respondents analysed from the survey was 312, which included $60.4 \%(n=191)$ males and $39.6 \%$ ( $n=125$ ) females. Based on age group, 3.5\% of the total fell within $18-19,59.2 \%$ within $20-29$, $13.0 \%$ within $30-39,13.9 \%$ within $40-49,9.5 \%$ within $50-59$, and $0.9 \%$ within 60 and above. $95.3 \%$ were Malaysian respondents while the rest were international. Most respondents who held a high school qualification were $15.8 \%, 24.7 \%$ with diploma, $49.4 \%$ with degree, and $7.6 \%$ were postgraduates. Meanwhile, the rest held a certain professional certificate. $16.8 \%$ of the respondents were employed in government sectors while 33.2\% worked in private sectors. $30.7 \%$ of the respondents were students, whereas $10.1 \%$ were unemployed. When asked whether they knew about the existence of Malaysia Prison Museum, 65.7\% were not aware, 33.9\% were aware, but most of them have had the experience of visiting Melaka at least once $(97 \%)$.

\section{Perception on Promotional Tools}

The respondents agreed that the frequency of advertisements makes them aware of the attraction (M:4.21, SD: 0.796). It also serves as a useful resource on the attraction (M:4.19, SD:0.836). They agreed with the use of national language and English language in advertisements (M:4.11, SD:0.906), and the ability of the contents to persuade (M:4.00 SD:0.997). Meanwhile, the respondents perceived that brochures give them truthful information on the attraction (M:3.98, SD:0.936) and the choice of colours of both text and page background in advertisements catches their attention (M:3.98, SD:0.974). The respondents perceived that printed advertisements are still very important for creating 
awareness of this attraction (M:3.91, SD:0.935). In addition, advertisements are also perceived to be helpful in making their travel decisions (M:3.87, SD: 1.125). As for public relations, the respondents mostly agreed that activities by the organization provide them information about the attraction (M:3.99, SD:0.772). They also perceived that this promotional tool allows their engagement with other visitors and the authority (M:3.88, SD:0.809). In fact, such public relations assist in making them well-informed of the attraction (M:3.62, SD:1.061) and minimize the cost to obtain information of the attraction (M:3.43, SD: 1.221).

Promotions through the internet were perceived to provide updated information (M:4.42, SD: 0.679). For internet and interactive marketing, respondents agreed that shared photos and videos on the internet make awareness (M:4.40, SD: 0.681). They also perceived that social media reviews give them confidence in searching the place (M:4.38, SD: 0.667). Availability of contents on the internet draws their attention to the attraction (M:4.34, SD:0.698). The respondents were more exposed to interactive and internet marketing rather than traditional marketing (M:4.32, SD:0. 761) and they noted that comments on social networks act as relevant sources of information (M:4.29, SD:0.732). Besides, the respondents perceived that posts in social media describe the reality of the attraction (M:4.25, SD:0.763). In addition, they agreed that the homepage of the museum website is considered to be the most important element in providing first impression of the attraction (M: 4.24, SD:0.888).

In this study, the researchers were able to analyse the tourists' intention to visit in which the respondents conceded recommendations of other users which affect their intentions to visit place (M:4.05, SD: 0.773). The respondents were willing to visit the place after they were aware of the promotions and media contents (M: 4.04, SD:0.747). They also sought positive opinions of others about the attraction (M:4.01, SD:0.756). Furthermore, the respondents planned to visit the place in the future (M: 3.93, SD:0.844). There were also positive views among the respondents to make Malaysia Prison Museum a popular tourist destination (M: 3.88, SD:0.840). Nonetheless, the respondents were least agreed with visiting the attraction compared to others (M:3.38, SD:0.983) and ranked the attraction to become their first choice when travelling to Melaka (M3.21, SD:1.234).

\section{Relationship between promotional tools and intention to visit}

To assess the relationship between promotional tools and intention to visit, a correlation analysis was conducted. Based on Table 1, promotional tools showed a moderate correlation with intention to visit $(r=0.58)$. This was based on the rule of thumb of correlation coefficient by Natarajan and Xiaojia (2016), which classified relationship between 0.4 and 0.6 as moderate. Moreover, both are in positive sign of $r$, which indicated the relationship of promotional tools and intention to visit as positive. $p=0.000$ which is less than 0.01 shows significant to each other. Thus, promotional tools were moderately positive to intention to visits.

As for Table 1 below, the variables such as advertising, public relations, and interactive and internet marketing were measured to determine the relationship with intention to visit. All variables were at moderate level of correlation, i.e., advertising ( $r=.537)$, public relations ( $r=.503)$, and interactive and internet marketing ( $r=.467)$. The three that showed a positive sign indicated a positive 
INTERNATIONAL JOURNAL OF ACADEMIC RESEARCH IN BUSINESS AND SOCIAL SCIENCES

Vol. 11, No. 13, Beyond 2021 and COVID-19 - New Perspective in the Hospitality \& Tourism Industry. 2021, E-ISSN: 2222-6990 @ 2021 HRMARS

relationship between advertising, public relations, and internet and interactive marketing towards intention to visit.

Table 1: Pearson correlation of variables to intention to visit

\begin{tabular}{|ccccc|}
\hline Correlation & Advertising & Public relations & $\begin{array}{l}\text { Interactive internet } \\
\text { marketing }\end{array}$ & $\begin{array}{l}\text { Intention to } \\
\text { visit }\end{array}$ \\
\hline Advertising & 1 & & & \\
\hline Public relations & $.686^{* *}$ & 1 & 1 & \\
\hline $\begin{array}{c}\text { Interactive internet } \\
\text { marketing }\end{array}$ & $.616^{* *}$ & $.572^{* *}$ & 1 \\
\hline \begin{tabular}{c} 
Intention to visit \\
\hline
\end{tabular} & $.537^{* *}$ & $.503^{* *}$ & $.467^{* *}$ & 1 \\
\hline
\end{tabular}

** Correlation is significant at the 0.01 level (2-tailed).

*Sample size $=316$

\section{Hypothesis Testing}

In determining the hypotheses, sig value for each of the variables must be observed. Sig value should not exceed $p=0.05$. The values shall be less than alpha 0.05 for the hypothesis to be accepted. After the analyses were conducted, the values of such were obtained: advertising; $t: 4.263, p=0.000$, public relations; $t: 3.162, p=0.002$, and interactive internet marketing, $t ; 2.796$, $p=0.005$. As all the values were less than $p=0.05$, hence, all hypotheses were accepted.

\section{Conclusion}

Promotional tools of Malaysia Prison Museum have contributed to tourists' intention to visit. The use of printed advertising such as brochures, signage, and online posters are able to be perceived in creating awareness among tourists to visit. It is similar to public relations programs where collaborations with local universities and exploration activities of the museum had gained the perception of tourists towards one of the promotional tools. In terms of interactive and internet marketing, the use of Facebook and the website has shown some positive influence in creating awareness.

It helps in receiving latest information of the attraction along with shared photos and videos that makes the positive impact. However, the analysis has shown that the value scored was the least for this variable. Thus, this may require attention from the management of the attraction. In today's trend, tourists and visitors are depending more on social media and digital marketing to help them make travel decisions. Management should do digital marketing with fresh conceptual and technical tools to articulate and tackle problems (Xiang, 2018). 
In general, all variables have relationships with intention to visit. Advertising placed the highest score followed by public relations and interactive and internet marketing to be correlated with intention to visit. Although they play an important role in creating awareness of the place, these variables however were placed under moderate score where promotional tools might not be a major contributor in enhancing tourist arrivals and motivating them to visit. Therefore, other aspects like facilities such as parking space, directory, signage, or settings (e.g., information inside of the attraction) must be analysed to determine the most influential contributor. Light (2017) conceded this matter under managing the dark tourism attraction to attract tourists, hence the management aspect should be focused on. The management aspect covers the operation of providing tour operators or tour guides which is also deemed helpful in influencing tourist intention to visit. Garcia (2012) stated that dark tourism attraction requires having a proper tour guide and tour operator to boost this market. This proposition is linked to Zahari et al (2016) urge for tourism stakeholders, especially tour operators to foresee dark tourism market as a selling point to be promoted in Malaysia. It is also said that the motivation of the tourists plays a role in their intention to visit certain attractions.

Even though the study highlighted a range of interesting, significant, and meaningful findings, several limitations were encountered, especially during the research processes. Firstly, the study was merely focused on promotional tools when there were other existing factors that can be the main contributors in solving the issue. Secondly, the result of this finding cannot be generalized to all museums and treated them as the same when this museum is pruned to be a dark tourism market. As a result, the researchers faced difficulties to link it to the market. Lastly, due to the current pandemic, the researchers had difficulties in explaining to the respondents about the research; therefore, some hardly cooperated. In creating public awareness and receive more tourists on this attraction, the management must not only focus on promotional strategy, but also other aspects, such as to develop a 360 google street view or a plan to improve the facilities. This study can also be a reference for other researchers who intend to explore this attraction genuinely. Moreover, the style of promotional tools will constantly be changing due to technology advancement. Regardless, dark tourism should still be preserved as the experience is different from the others. Therefore, it is essential for researchers to continue investigating the aspects that influence intention to visit to the attraction.

\section{Corresponding Author}

Arni Abdul Gani. Faculty of Hotel and Tourism Management, Universiti Teknologi MARA, Puncak Alam Campus, 42300, Puncak Alam, Selangor, Malaysia.

E-mail: arni@uitm.edu.my

\section{References}

Alananzeh, O. A., Amyan, M. M., Alghaswyneh, O. F. M., Shatnawi, H., \& Jawabreh, O. (2015). Managing promoting tourism product of the golden triangle in Jordan. International Journal Human Social Science, 5(9), 197-207.

Arshad, M., \& Aslam, T. (2015). The impact of advertisement on consumer's purchase intentions. SSRN 2636927 or https:// https://dx.doi.org/10.2139/ssrn.2636927 
Bhuiyan, M. A. H., Siwar, C., \& Ismail, S. M. (2013). Tourism Development in Malaysia from the Perspective of Development Plans. Asian Social Science, 9(9), 11-18.

Braithwaite, D., \& Lee, Y.L. (2006). Dark tourism, hate and reconciliation: The Sandakan experience. IIPT Occasional paper, No.8 March 2006, Global Educator's Network of the International Institute for Peace through Tourism. https://www.semanticscholar.org

Cavlek, N. (2002). Tour operators and destination safety. Annals of Tourism Research, 29(2), 478496. https://doi.org/10.1016/S0160-7383(01)00067-6

Clarke, R., Dutton, J., \& Johnston, A. (2014). Shadow zones: dark travel and postcolonial cultures. Postcolonial Studies, 17(3), 221-235, https://doi.org/10.1080/13688790.2014.993426

Farooq, U. (2018). Marketing Mix 4Ps, 7Ps and 4Cs. Marketing Tutor. https:// https://www.marketingtutor.net/marketing-mix/

Fiddler, M. (2011). 'A 'system of light before being a figure of stone': The phantasmagoric prison'. Crime Media Culture, 7 (1), 83-97.

Foley, M., \& Lennon, J. (1996). JFK and dark tourism - a fascination with assassination, International Journal of Heritage Studies, 2(4), 198-211.

Garcia, B. R. (2012). Management issues in dark tourism attractions: The case of ghost tours in Edinburg and Toledo. Journal of Unconventional Parks, Tourism and Recreation Research, 4(1), 14-19.

Govers, R., \& Go, F. M. (2003). Deconstructing destination image in the information age. Information Technology and Tourism, 6, 13-29.

Hartmann, R. (2014). Dark tourism, thanatourism, and dissonance in heritage tourism management: new directions in contemporary tourism research. Journal of Heritage Tourism, 9(2), 166-182. https://doi.org/10.1080/1743873X.2013.807266

Hennessey, S. M., Yun, D., \& MacDonald, R. (2016). Influencing the intentions to visit a destination: The case of potential first-time and repeat visitors. Paper presented at Travel and Tourism Research Association 2009 Annual Conference, Hawaii.

Hidayat, A., \& La Are, R. (2018). The impact of social media as promotion tools towards intention to visit: Case of Batu, Malang, Indonesia. Paper presented at the 2nd International Conference on Tourism, Gastronomy, and Tourist Destination (ICTGTD 2018).

Jahnke, D. (2013). Dark tourism and destination marketing. (Master thesis, Kajaani University of Applied Sciences, Kajaani, Finland).

https://www.theseus.fi/bitstream/handle/10024/64693/Jahnke_Daniela.pdf?sequence=1\& isAllowed $=y$

Kaur, G. (2017). The importance of digital marketing in the tourism industry. International Journal of Research-Granthaalayah, 5(6), 72-77.

Kennedy, A. (2016). A study to assess the promotional methods that are most influential on customers who visit UK theatres. A case study on the Bristol Hippodrome. (Bachelor Degree thesis, Cardiff Metropolitan University, United Kingdom). https://repository.cardiffmet.ac.uk/bitstream/handle/10369/8246/Dissertation\%20Alice\%2 OKennedy\%202016.pdf?sequence=1\&isAllowed=y

Kešetović, Ž. (2011). Terrorism and tourist industry: Media influences in shaping risk perceptions. Nauka, bezbednost, policija (NBP), 16 (3), 19-34. 
Khamis, M., \& Shariff, F. (2016). Motivation factors, satisfaction and return intention towards dark tourism sites in Malaysia. In S. Mohd Radzi, M. H. Mohd Hanafiah, N. Sumarjan, Z. Mohi, D. Sukyadi, K. Suryadi, P. Purnawarman (Eds.) Heritage, culture and society: Research agenda and best practices in the hospitality and tourism industry, (pp.121-124). Taylor \& Francis Group, London.

Kokemuller, N. (2019). Marketing Promotional Tools. Houston Chronicle. https://smallbusiness.chron.com/marketing-promotional-tools-60473.html

Leung, X., \& Bai, B. (2013), “How motivation, opportunity, and ability impact travelers' social media involvement and revisit intention". Journal of Travel and Tourism Marketing, 30, Nos 1/2, 5877.

Light, D. (2017). Progress in dark tourism and thanatourism research: An uneasy relationship with heritage tourism. Tourism Management, 61, 275-301.

Logan, W., \& Reeves, K. (2009). Introduction: Remembering places of pain and shame, W. Logan, K. Reeves (Eds.), Places of pain and shame: Dealing with 'difficult past', Routledge, London, pp. 1-14

Mahbob, S., Zahari, M., Zainuddin, Z., Suhaimi, M., \& Sumarjan, N. (2013). Educational value of dark tourism: Tour operators perceived importance and action behaviour. In N. Sumarjan, M. S. Mohd Zahari, R. S. Mohd, M. Zurinawati, H. M. Hafiz Mohd, B. M. Faeez Saiful, Z. Artinah, S. Bakhtiar (Eds). Hospitality and tourism: Synergizing creativity and innovation in research, CRC Press, London. https://doi.org/10.1201/b16064.

Mahorm, S. (2018). More tourists visit Melaka. The Star. https://www.thestar.com.my/metro/metro-news/2018/02/01/more-tourists-visit-melakanumber-of-visitors-the-highest-seen-by-state-in-years/

Makosa, D. (2019). Effectiveness of using digital marketing as a destination branding strategy in the tourism sector: A tourism players' perspective. (Master in Business Leadership, Bindura University of Science Education, Bindura, Zimbabwe). https:// https://ir.buse.ac.zw/bitstream/handle/11196/2501/Makosa.pdf?sequence=1\&isAllowed=y Masanti, M. (2016) Understanding Dark Tourism Acceptance in Southeast Asia: The Case of WWII Sandakan-Ranau Death March, Sabah, Malaysia. In: Mandal P., Vong J. (Eds) Development of Tourism and the Hospitality Industry in Southeast Asia. Managing the Asian Century. Springer, Singapore. https://doi.org/10.1007/978-981-287-606-5_8

Mat Som, Z. (2014). Guided by guards. The New Straits Times. https://www.nst.com.my/news/2015/09/54604/guided-guards

Minic, N. (2012). Development of "dark" tourism in the contemporary society. Journal of the Geographical Institute Jovan Cvijic, SASA, 62, 81-103. https://doi.org/10.2298/IJGI1203081M

Peattie, S., \& Peattie, K. (1994). Sales Promotion. The Marketing Book, 3, 534-554. London: Pittman. PERZIM. (2019). Statistik Pelawat Muzium PERZIM. https://www.perzim.gov.my/ms/perzim/statistik-pelawat-muzium/

Pike, S. (2004). Destination Marketing Organisations. Oxford: Elsevier. UK. Robinson, P. (Editor); Heitmann, S. (Editor); Dieke, P.U.C. (Editor). Research Themes for Tourism. Wallingford, Oxon, GBR: CABI Publishing, 2011. 205-217.

Ross, J. I. (2012). Touring imprisonment: A descriptive statistical analysis of prison museums. Tourism Management Perspectives, 4, 113-118. https://doi.org/10.1016/j.tmp.2012.07.001. 
Saha, S. (2020). Dark Tourism: Sector Overview \& Analysis. https://www.futuremarketinsights.com/reports/dark-tourism-sector-overview

Seitel, F. P. (2001). The Practice of Public Relations. Prentice Hall, New Jersey.

Sharpley, R. (2009). Travels to the edge of darkness: towards a typology of "Dark Tourism". In Taking Tourism to the Limits: Issues, Concepts and Managerial Perspectives. https://doi.org/10.1016/B978-0-08-044644-8.50023-0.

Sharpley, R., \& Stone, P. R. (2009). The darker side of travel: The theory and practice of dark tourism. UK: Channel View Publications.

Stone, P. (2006). A Dark Tourism Spectrum: Towards a typology of death and macabre related tourist sites, attractions and exhibitions. Tourism: An Interdisciplinary International Journal, 54(2), 145-160.

Stone, P. (2009). The Darker Side of Travel: The Theory and Practice of Dark Tourism. Bristol: Channel View Publications. UK.

Stone, P., \& Sharpley, R. (2008). Consuming dark tourism: A thanatological perspective. Annals of Tourism Research, 35 (2), 574-595.

Tan, G., \& Lim, S. (2018). The "Pearl of the orient" as a dark tourism destination in Malaysia. International Journal of Tourism Cities, 4(1), 68-80. https://doi.org/10.1108/IJTC-04-20170023.

Vogt, C., Winter, G., \& Fried, J. (2005). Predicting homeowners' approval of fuel management at the Wildland - Urban interface using the theory of reasoned action. Society and Natural Resources, 18, 337-354. https://doi.org/10.1080/08941920590915242.

Walby, K., \& Piche, J. (2011). The polysemy of punishment memorialization: Dark tourism and Ontario's penal history museums. Punishment and Society, 13, 451-472. https://doi.org/10.1177/1462474511414784.

Welch, M., \& Macuare, M. (2011). Penal tourism in Argentina: Bridging Foucauldian and neoDurkheimian perspectives. Theoretical Criminology, 15, 401-425. https://doi.org/10.1177/1362480610391354.

Weng, L., \& Huang, Z. (2018). A study of tourism advertising effects: advertising formats and destination types. Paper presented at Travel and Tourism Research Association 2009 Annual Conference, Hawaii.

Wright, T., \& Cropanzano, R. (2000). Psychological well-being and job satisfaction as predictors of job performance. Journal of Occupational Health Psychology, 5, 84-94. https://doi.org/10.1037/1076-8998.5.1.84.

Xiang, Z. (2008). From digitization to the age of acceleration: On information technology and tourism. Tourism Management Perspectives, 25, 147-150.

Xiang, Z., \& Gretzel, U. (2010), Role of social media in online travel information search, Tourism Management, 31 (2), 179-188.

Yilmaz, C. (2009). Tarihi Sinop Kalesi Cezaevi. Eastern Geographical Review, 22, 1-16.

Zahari, M. S. M., Hanafiah, M. H., Mahboob, S. S. S., \& Zain, N. A. (2016). Dark tourism: Is it a growth segment for the Malaysia tourism industry. Tourism and Hospitality Management, 22, 47-56. https://doi.org/10.20867/thm.22.1.5. 